Studia Slavica Savariensia 2016. 1-2. 349-353

DOI: $10.17668 /$ SSS.2016.1-2.349

\author{
Татьяна Пчелкина - Михай Фрешли \\ (Костанай, Казахстан - Сомбатхей, Венгрия)
}

\title{
«КОЧЕВНИКИ» В КУЛЬТУРНОЙ СЕТИ - ТОЛЕРАНТНОСТЬ КАК ПОКАЗАТЕЛЬ СФОРМИРОВАННОСТИ ЛИЧНОСТИ
}

\begin{abstract}
The article is devoted to approach different cultural situations in the world. The authors argue that tolerant behavior is the fundamental question in the field of intercultural communication.
\end{abstract}

Keywords: tolerant, culture, intercultural communication, community

В современном мире все большую остроту приобретает проблема взаимодействия между народами, представителями различных культур, социальных групп и возрастных категорий. По мнению ученых, главным условием становления гуманного общества (Р.Р. Валитова, М.П. Мчедлов, В.А. Тишков, Н. В. Круглова, П.Ф. Комогоров, П.В. Степанов, В.А. Лекторский Е.В. Магомедова, В.М. Золотухин) является именно воспитание толерантной личности (MENDUS 1989: 171).

Проблема толерантности была исследована многими учеными, в частности Дж. Мидом и Г. Блумером. Для объяснения понятия они обращались к описанию процессов межличностного взаимодействия, разделяя понятия толерантности и терпимости: «Проявление толерантности также не означает терпимости к социальной несправедливости, отказа от своих убеждений или уступки чужим убеждениям, а также навязывания своих убеждений другим людям» (PAMA3АН 2004: 182).

Проблема толерантности не нова, ее истоки можно обнаружить в литературе 18-19 веков. В современном обществе актуализируется обсуждение и изучение более широкого круга проблем, связанных с этим понятием. В большинстве научных источников толерантность понимается как способность человека воспринимать чужое мнение, образ жизни, особенности поведения. Фактически толерантный человек признает за другими людьми право быть собой.

Толерантность это терпимость, способность понять другого человека, особенности его мироощущения. В современном мире глобализации проблема толерантности приобретает особенно актуальное звучание. Прежде всего, необходимо определить разные направления проблемы: 
1.межнациональная толерантность;

2.социальная толерантность;

3. толерантность восприятия мира;

4.гендерная толерантность и т.п.

Наиболее серьезной является проблема формирования межнациональной толерантности, ее воспитание связано с глубоким пониманием особенностей культуры, традиций народа, принятием системы ценностей. Формирование ее составляющих связано с длительной систематической работой семьи и общества. Первоначальные элементы терпимости формируются именно в семье. Это способность ребенка осознать существование иных понятий и представлений.

Социальная толерантность предполагает понимание представителей различных социальных групп, вне зависимости от собственной принадлежности. Она требует понимания проблем социального характера, умения их воспринимать и помогать в их решении. Социальная толерантность, на наш взгляд, в большей степени воспитывается обществом, общественными институтами.

Толерантное восприятие мира связано с философским пониманием его проблем, осознанием общечеловеческих понятий, законов развития мира, независимости действительности от индивидуального миропонимания.

Вопросы гендерного равенства в последние десятилетия перестали быть остро социальными ввиду серьезных достижений в обществе. Это касается не только стран Европы, но и Востока. Тем не менее, возникает вопрос, связанный с существованием в обществе гендерных стереотипов, влияющих на социализацию личности, ее развитие и реализацию.

Толерантность является необходимым качеством современной личности, т.к. ее наличие позволяет человеку оставаться терпимым, восприимчивым и чутким к другим людям, идеям и мнениям.

Один из важных аспектов существующей проблемы - четкое определение границ, т.е. обстоятельств, не позволяющих оставаться безучастным и равнодушным.

По нашему мнению, толерантность заканчивается там, где унижается или уничтожается человеческая личность, нарушается ее целостность и самоценность. Мы глубоко убеждены, что толерантность предполагает спор, обсуждение, но не унижение и давление.

При этом важно сделать уточнение: под личностью мы понимаем человека, обладающего высоким уровнем развития, способного управлять своими эмоциями и корректировать свое поведение, исходя из принципов сосуществования в мире.

В 1995 году резолюцией Генеральной конференции ЮНЕСКО утверждена Декларация принципов толерантности: «Терпимость означает уважение, принятие и правильное понимание богатого многообразия культур нашего мира, наших форм самовыражения и способов 
проявлений человеческой индивидуальности. Ей способствуют знания, открытость, общение и свобода мысли, совести и убеждений. Терпимость - это гармония в многообразии» (СФТ 2009: 91).

В философском энциклопедическом словаре даётся следующее определение толерантности: «терпимость к иного рода взглядам, нравам, привычкам. Толерантность необходима по отношению к особенностям различных народов, наций и религий. Она является признаком уверенности в себе и сознания надёжности своих собственных позиций. Признаком открытого для всех идейного течения, которое не боится сравнения с другими точками зрения и не избегает духовной конкуренции» (ФЭС 2009: 457).

В словаре философских терминов подчёркивается различие между толерантностью и терпимостью. «Толерантность не сводится к простой терпимости. Терпимость подчёркивает способ отношения к неприятным или неприемлемым объектам - снисходительное их допущение или вынужденное терпение без применения насилия. За такой внешней формой поведения зачастую скрывается внутренняя враждебность и незнание другого. В отличие от терпимости толерантность подразумевает право личности на сохранение её автономии. Как качество личности толерантность предполагает настроенность на паритетный диалог, на познание нового, «чужого», а также не исключает возможности изменения системы взглядов и представлений индивида» (ЮНЕСКО 2001: 12).

Академик М.Бахтин высказал идею диалогичности, объясняя ею не только специфику взаимодействия автора и читателя, автора и героя, но и предполагая ее более широкое применение. «Концепция М.М. Бахтина, утверждавшего, что дорога к объяснению души человека лежит через анализ диалогизма его сознания, привносит в систему антропологических размышлений серьезную и глубокую новизну, - этот тезис не вызывает сомнений у большинства современных исследователей творчества замечательного российского мыслителя» (PSYJOURNAL 2011).

Толерантность подразумевает стремление к диалогу, обсуждению, нахождению компромисса. Именно компромисс является основой мирного сосуществования представителей разных национальностей, культур, социальных, религиозных и возрастных групп. Понимая толерантность как добродетель и социальное благо, мыслители разных эпох обращались к нравственным аргументам, содержащимся в евангельских текстах. Именно там заложены истоки нравственноэтических норм, без которых невозможно существование личности.

Процесс воспитания межкультурной толерантности студентов - это сложный процесс, имеющий четко выделенные этапы.

Первый связан с теоретическим обсуждением понятий, связанных с проблемой толерантности. Это этап информационного насыщения, в который происходит накопление информации. 
На втором рефлексивном, студент должен осмыслить прочитанное и получить мотивацию. Именно она будет способствовать дальнейшему продвижению личности.

Третий этап связан с вступлением студента в сам процесс толерантного существования с миром. На наш взгляд, он является наиболее сложным, в этот период теоретические посылы становятся или не становятся истинным убеждением. Современная парадигма образования связана с акцентированием внимания на вопросах гуманизации процесса обучения и воспитания, происходит постепенный выход из одномерного пространства, приобщение студентов к многополярному миру и его идеям.

Так как толерантность является характеристикой любой личности, вне зависимости от ее культурной принадлежности, eе формирование возможно через онтологические, общекультурные ценности.

Первостепенная задача в процессе воспитания достойной личности связана, таким образом, с активным приобщении студентов к мировой культуре, что является главным рычагом в формировании развитой толерантной личности.

Подходя к изучению вопроса со стороны межкультурной коммуникации, перед нами стоит хорошая модель - теория культурных сетей. Воспринимая человеческую культуру сложной паутиной межчеловеческих связей, можем моделировать вопрос толерантности между социальными группами.

Разные культурные группы не замкнуты в самом себе, хотя они образуют многоцветные микромиры, связываются людьми, которые являются посредниками и одновременно толкователями отдельных культур.

В историческом размере такую функцию выполняли кочевые народы кочевники. Они, обладая своими традициями и обычаями, - включали в свою культуру элементы других народов и передавали их.

Кочевой образ жизни не только сохранил для будущих поколений элементы национальной толерантности, но и сам служил живым примером взаимопонимания разных народов.

Таким образом, гунны, варяги или половцы были одновременно и завоевателями и ранними примерами взаимодействия. Монголо-татарское нашествие на Русь было мрачным периодом русской истории, однако характеризовалось религиозной свободой и развитыми почтовыми путями.

В заключении можем сказать, что толерантный человек определяется нами как зрелая личность. А формирование ее связано с общим развитием культурного кругозора.

Именно культура позволит сформировать личность, способную быть представителем мира, понимающим и воспринимающим иное видение, 
иные культурные ценности, без потери своей национальной идентичности.

\section{Литература}

РАМАЗАН 2004 = РАМАЗАН Г.А. Этнополитология: учебное пособие для студентов высших учебных заведений. СПб., 2004. 313.

СФТ 2009 = Словарь философских терминов. Науч. ред. В.Г. Кузнецов. Москва, 2009. 731 .

ФЭС 2009 = Философский энциклопедический словарь. Москва, 2009. 570.

ЮНЕСКО $2001=$ Декларация принципов толерантности. Утверждена резолюцией 5.61 Генеральной конференции ЮНЕСКО от 16 ноября 1995 года // Век толерантности: Научно-публицистический вестник. Москва, 2001. 12.

MENDUS $1989=$ MENDUS S. Toleration and the limits of liberalism. Henndmills etc.: Macmillan, 1989. IX. 171.

PSYJOURNAL 2011 = Диалогизм M.М.Бахтина в контексте естественнонаучной психологии // Консультативная психология и психотерапия 2011. № 2. $<\underline{\text { http://psyjournals.ru/mpj/2011/n2/46930.shtml }>}$ 